\title{
Flipbook Bagian-Bagian Darah dan Pembekuan Darah dengan Pengayaan Proses Penyembuhan Luka Sayat
}

\section{Flipbook Of Blood Components and Blood Clotting Enriched with Wound Healing Process}

\author{
Habibina, Eko Sri Wahyuni, Wolly Candramila* \\ Pendidikan Biologi, FKIP, Universitas Tanjungpura Pontianak, Indonesia \\ *wolly.candramila@fkip.untan.ac.id \\ diterima : 20 April 2021; dipublikasi : 30 Oktober 2021 \\ DOI: 10.32528/bioma.v6i2.3997
}

\begin{abstract}
ABSTRAK
Penggunaan media cetak flipbook dianggap masih memiliki keunggulan dibandingkan media elektronik terutama pada situasi dan kondisi yang tidak memungkinkan. Penelitian ini bertujuan mendeskripsikan proses pengembangan dan mengetahui kelayakan media flipbook untuk membantu proses belajar mengajar Submateri Bagian-bagian Darah dan Pembekuan Darah. Metode penelitian menggunakan tiga dari empat tahap dalam model 4D (define, design, develop, dessiminate). Validasi media dilakukan oleh 5 orang validator yang terdiri dari aspek format, isi, dan bahasa dengan 11 kriteria. Hasil analisis uji kelayakan flipbook diperoleh nilai CVR dan CVI sebesar 0,99 atau sesuai dengan nilai minimum untuk content validity Lawshe. Produk flipbook yang diperkaya informasi proses penyembuhan luka sayat dinyatakan layak digunakan sebagai media pembelajaran Submateri Bagian-bagian Darah dan Pembekuan Darah kelas XI SMA. Untuk melihat kebermaknaan topik pengayaan yang ditambahkan perlu dilakukan pengujian secara langsung dalam proses pembelajaran.
\end{abstract}

Kata Kunci: Pengembangan, Flipbook, Submateri Bagian-bagian Darah dan Pembekuan Darah

\begin{abstract}
The use of printed media such as flipbooks is considered to have advantages over electronic media, especially in good situations and conditions that are not possible. This development research aimed to describe the process of developing a flipbook media to assist the teaching and learning process in the Sub Material of Blood Components and Blood Clotting. The research method used three of the four stages in the 4D model (define, design, develop, dessiminate). Media validation was performed by 5 validators consisting of 11 criteria in format, content, and language aspects. Flipbook feasibility test analysis results obtained CVR and CVI values of 0,99 or in accordance with the minimum value for Lawshe's content validity. The flipbook product enriched with the wound healing process was deemed fit for use as a learning medium in the Sub Material of Blood Components and Blood Clotting for class XI SMA. However, the significance of the added enrichment topic needs to be tested directly in the learning process.
\end{abstract}

Key Words: Development Research, Flipbook, Sub Material of Blood Components and Blood Clotting 


\section{PENDAHULUAN}

Biologi sering disebut sebagai mata pelajaran yang sulit karena karakteristik dari materi cenderung menuntut peserta didik menghafal dan mengingat bahasa latin (Lestari dkk., 2016, p. 84; Lubis \& Manurung., 2010, p. 186). Permasalahan tersebut dapat diatasi oleh guru dengan memanfaatkan media pembelajaran sehingga minat dan motivasi belajar biologi akan meningkat. Kontribusi penggunaan media pada kegiatan pembelajaran membuat penyampaian pesan menjadi terstandar, meningkatkan kualitas dalam pembelajaran, dan peran guru berubah ke arah yang lebih positif (Nugroho dkk., 2016, p. 2). Pemilihan media pembelajaran dilihat dari beberapa kriteria diantaranya harus sesuai dengan tujuan pembelajaran yang ingin dicapai, ketepatan dalam mendukung isi pelajaran, praktis, luwes, dan tahan lama, guru memiliki keterampilan dalam menggunakannya, pengelompokan terhadap sasaran, serta mutu teknis (Arsyad., 2014, p. 74-76).

Penggunaan media pembelajaran dalam kegiatan belajar mengajar dapat memberikan dampak positif terhadap peserta didik. Salah satu media pembelajaran yang dapat digunakan yaitu media cetak seperti flipbook. Penggunaan pada media flipbook terbukti dapat meningkatkan motivasi peserta didik dan berpengaruh terhadap hasil belajar peserta didik. Sesuai dengan pernyataan Sakhowati dkk. (2020, p. 46), bahwa penggunaan media flipbook dapat meningkatkan hasil belajar peserta didik. Sejalan dengan penelitian yang dilakukan oleh Andri dkk. (2013, p. 6) dalam Materi Sistem Gerak Manusia di kelas VIII SMP, persentase ketuntasan hasil belajar siswa pada kelas eksperimen dengan media flipbook $(87,88 \%)$ lebih tinggi dibandingkan kelas kontrol (62,50\%). Penelitian juga dilakukan oleh Lestari dkk. (2016, p. 6) pada materi virus di SMA mendapat perbedaan persentase ketuntasan hasil belajar pada kelas eksperimen dengan media flipbook (62,50\%) lebih tinggi dibanding kelas kontrol (40\%). Penelitian lainnya, Mulyadi dkk. (2016, p. 300) menunjukkan adanya peningkatan keterampilan berfikir kreatif peserta didik selama kegiatan belajar mengajar menggunakan media pembelajaran flipbook.

Setiap media pembelajaran memiliki kelebihan dalam penggunaanya, begitu juga dengan media flipbook. Kelebihan media flipbook dibandingkan sumber belajar lainnya terdapat pada penyajiannya. Hal tersebut sesuai dengan pendapat Maghfirothi dkk. (2013, p. 44) bahwa penyajian materi dalam flipbook sudah dalam bentuk inti sari Habibina et al., Flipbook Bagian-Bagian Darah 
dan diambil pokok-pokoknya serta terdapat berbagai ilustrasi berupa gambar, bagan, diagram, dan kartun. Berbagai ilustrasi tersebut bertujuan untuk menarik perhatian, memperjelas materi yang disajikan, mengilustrasikan berbagai fakta yang cepat dilupakan, serta mempermudah peserta didik untuk memahami berbagai istilah IPA. Selain itu, kelebihan pada media flipbook yaitu dapat memasukkan file berupa pdf, gambar, video, dan animasi sehingga membuat media menjadi lebih menarik dan interaktif (Maf'ula dkk., 2017, p. 1452). Dengan kelebihan-kelebihan tersebut, media flipbook seyogyanya dapat mengatasi kesulitan belajar biologi khususnya pada materimateri yang membutuhkan penyederhaan konsep dan penampilan gambar-gambar sebagai penjelas.

Hasil wawancara dengan tiga orang guru biologi di SMAN 5, SMAN 7, dan SMAS Mujahidin di Kota Pontianak diperoleh informasi bahwa salah satu materi yang perlu dibantu dengan pengembangan media yang tepat adalah Submateri Bagian-bagian Darah dan Pembekuan Darah di kelas XI. Ketiga guru sudah menggunakan media slide PowerPoint dalam proses pembelajarannya namun belum pernah menggunakan media cetak termasuk media flipbook. Pembelajaran menggunakan media PowerPoint lebih menempatkan guru sebagai pelaku yang aktif sehingga menyebabkan peserta didik relatif lebih pasif karena hanya menerima dan mengikuti apa yang disampaikan oleh guru (Simamora \& Mukhtar, 2015, p. 212). Oleh karena itu, dengan menggunakan media cetak berupa flipbook diharapkan dapat meningkatkan peran peserta didik dalam kegiatan pembelajaran. Sesuai dengan penyataan Wahyuliani dkk. (2016, p. 24), flipbook mempunyai keistimewaan tersendiri yaitu dapat mengembangkan kreatifitas peserta didik. Selain itu, penggunaan media cetak seperti flipbook dianggap masih memiliki keunggulan dibanding media elektronik terutama pada situasi dan kondisi yang kurang memungkinkan, misalnya tidak adanya sumber listrik atau rendahnya fasilitas sarana dan prasarana sekolah.

Flipbook yang dikembangkan dalam penelitian ini berupa lembaran-lembaran kertas menyerupai kalender dengan ukuran 21 x $28 \mathrm{~cm}$ mengacu pada Nurseto (2011, p. 25) dan berisi materi biologi khususnya submateri bagian-bagian darah dan pembekuan darah kelas XI SMA. Pengayaan dengan informasi tentang proses wound healing dalam media flipbook diharapkan dapat memperjelas konsep fungsi bagian-bagian darah secara langsung dalam mekanisme pembekuan darah sesuai dengan KD 3.6. Tujuan penelitian Habibina et al., Flipbook Bagian-Bagian Darah 
ini adalah untuk menjelaskan proses pengembangan media flipbook dalam membantu proses belajar mengajar Submateri Bagian-bagian Darah dan Pembekuan Darah. Didalam flipbook yang dikembangkan ini memuat materi sistem peredaran darah khususnya membahas mengenai bagian-bagian darah dan mekanisme pembekuan darah. Untuk meningkatkan kedalaman isi materi dalam flipbook, dilakukan dengan cara pengayaan dari hasil penelitian tentang proses penyembuhan luka sayat yang sudah dilakukan oleh Habibina (2020).

\section{METODE}

Penelitian dilaksanakan mulai bulan April - Agustus 2020. Penelitian ini menggunakan bentuk deskriptif dengan model pengembangan (development research) mengacu pada model penelitian 4D (define, design, develop, dessiminate) menurut Thiagarajan et al. (1974, p. 5). Pada penelitian ini, metode penelitian dibatasi hingga tahap 3 yaitu pengembangan (develop). Tahap pertama yaitu tahap penetapan (define) merupakan tahap analisis yang memfokuskan pada situasi yang dihadapi oleh guru, karakteristik siswa, dan mengenai konsep-konsep yang akan diajarkan menggunakan media pembelajaran (Rohdiani \& Rakhmawati., 2017, p. 107). Tahap ini dilakukan dengan mewawancarai 3 orang guru Biologi SMA di Pontianak terkait dengan penggunaan metode dan media yang digunakan guru dalam kegiatan pembelajaran khususnya Submateri Bagian-bagian Darah dan Pembekuan Darah. Tahap kedua yaitu perancangan (design) merupakan tahapan dalam pembuatan media dari konsep yang sudah disiapkan pada tahapan sebelumnya (Rohdiani \& Rakhmawati., 2017, p. 108). Pada tahap ini materi yang telah terkumpul kemudian didesain dalam media flipbook. Perancangan media flipbook meliputi penentuan bentuk dan ukuran flipbook yaitu berupa lembaran-lembaran kertas yang menyerupai kalender berukuran 21 x $28 \mathrm{~cm}$ mengacu pada Nurseto (2011, p. 25), penyusunan isi flipbook meliputi cover, petunjuk penggunaan, kata pengantar, daftar isi, kompetensi dasar, indikator, tujuan pembelajaran, pendahuluan, uraian materi, soal evaluasi, kunci jawaban, daftar pustaka, dan glosarium. Selanjutnya, tahap ketiga yaitu pengembangan (development) merupakan tahapan di mana media yang sudah dirancang akan dikonsultasikan untuk diperbaiki dan dikembangkan sesuai dengan kebutuhan pembelajaran (Rohdiani \& Rakhmawati., 2017, p. 108). Pada tahap ini akan dilakukan penilaian ahli terhadap 
media melalui proses validasi. Validasi ini bertujuan untuk mengetahui kelayakan dari media flipbook Submateri Bagian-bagian Darah dan Pembekuan Darah. Lembar validasi yang digunakan hasil modifikasi dari lembar validasi flipbook Syafrizal dkk (2014). Validasi media flipbook dilakukan melalui dua tahapan, diantaranya tahap pertama yaitu validasi lembar instrument media flipbook dan tahap kedua yaitu validasi pada media flipbook.

Subjek penelitian yang digunakan adalah 5 orang validator meliputi 2 orang dosen yang terdiri dari 1 orang dosen Pendidkan Biologi FKIP Untan dan 1 orang dosen Pendidikan Kimia FKIP Untan, serta 3 orang guru Biologi SMA/MA di Kota Pontianak. Instrumen yang digunakan adalah lembar validasi media. Teknik pengumpulan data dilakukan dengan cara membagikan media pembelajaran berupa media cetak yaitu flipbook beserta lembar validasi media kepada validator. Validasi flipbook terdiri dari 3 aspek penilaian yang meliputi aspek format, isi, dan bahasa dengan 11 kriteria. Pengukuran instrumen validasi media flipbook menggunakan skala Likert yaitu Sangat Baik (SB) bernilai 4, Baik (B) benilai 3, Kurang Baik (KB) benilai 2, dan Tidak Baik (TB) benilai 1. Hasil dari validasi flipbook dianalisis menggunakan Conten Validity Ratio (CVR) menurut Lawshe (1975, p. 567). Setelah nilai CVR diperoleh, kemudian dilakukan perhitungan nilai Conten Validity Index (CVI). Flipbook akan dinyatakan valid dan layak digunakan apabila perhitungan akhir dari CVR dan CVI telah memenuhi nilai batas minimum Lawshe yaitu 0,99 untuk 5 orang validator.

\section{HASIL DAN PEMBAHASAN}

Pada proses pengembangan perangkat pembelajaran berbasis media flipbook ini menggunakan tahapan Development Research yang mengacu pada metode penelitian 4D (define, design, develop, dessiminate) menurut Thiagarajan et al. (1974, p. 5). Pada penelitian ini menggunakan tiga dari empat tahapan dalam model 4D yaitu tahap penetapan, perancangan, dan pengembangan.

1. Tahap Penetapan (define)

Tahap ini berupa penentuan syarat-syarat untuk pembuatan bahan materi dan media yang dilakukan dengan menganalisis tujuan dan batasan dari media pembelajaran yang akan digunakan (Rohdiani \& Rakhmawati., 2017, p. 107). Tahap penetapan ini dilakukan dengan mewawancarai 3 orang guru biologi SMA/MA di 
Kota Pontianak. Wawancara dilakukan dengan tujuan untuk memperoleh informasi mengenai metode dan media pembelajaran yang digunakan oleh guru saat menyampaikan submateri bagian-bagian darah dan pembekuan darah kelas XI SMA. Berdasarkan hasil wawancara diperoleh bahwa proses pembelajaran pada submateri bagian-bagian darah dan pembekuan darah dilakukan dengan metode ceramah dan diskusi serta media yang digunakan yaitu slide PowerPoint.

\section{Tahap Perancangan (Design)}

Tahap perancangan termasuk kedalam perancangan media flipbook. Secara format, flipbook berbentuk seperti kalender dengan ukuran 21 x $28 \mathrm{~cm}$ mengacu pada Nurseto (2011, p. 25) dan terdiri dari 29 halaman. Secara isi, flipbook memuat Submateri Bagian-bagian darah dan Pembekuan Darah serta ditambahkan hasil penelitian tentang proses penyembuhan luka sayat oleh Habibina (2020).

Perancangan media flipbook pada penyusunan tata letak dikembangkan dari modifikasi Ariani dkk. (2017, h. 4) meliputi cover yang memuat judul, identitas dari pembuat, dan instansi yang terkait. Bagian depan terdiri dari petunjuk penggunaan, kata pengantar, daftar isi, kompetensi dasar, indikator, tujuan pembelajaran, dan pendahuluan. Bagian isi memuat materi sistem peredaran darah khususnya membahas mengenai bagian-bagian darah dan mekanisme pembekuan darah disertai hasil penelitian. Bagian penutup berisi soal evaluasi, kunci jawaban, daftar pustaka, dan glosarium.

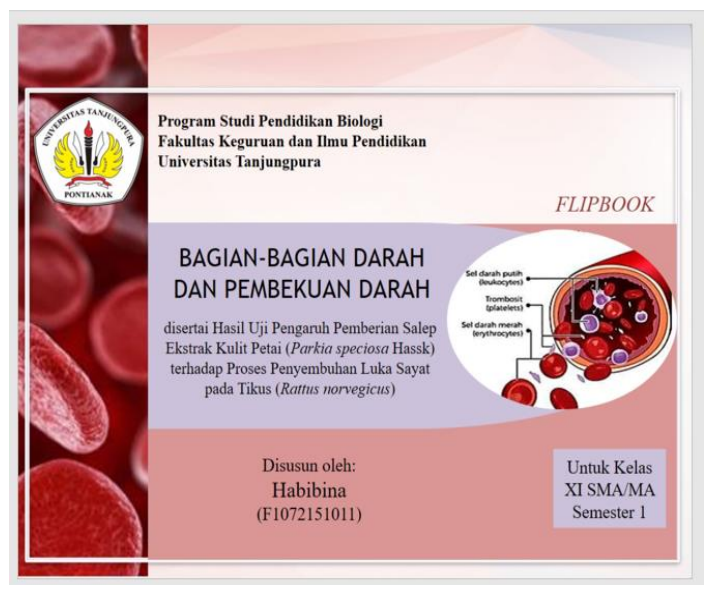

Gambar 1. Cover media pembelajaran Flipbook

Bagian cover flipbook sebagaimana tampak pada gambar 1 menampilkan beberapa kombinasi warna. Warna dapat memberikan kesan/mood pada keseluruhan 
visual, meningkatkan pembelajaran dan pemahaman, serta gambar berwarna dapat menarik perhatian (Monica \& Luzar, 2011, p. 1093). Tampilan cover didominasi warna merah untuk menyesuaikan dengan karakteristik "darah" yang merupakan tema dari flipbook. Gambar sel-sel darah yang dibingkai dalam lingkaran bertujuan untuk memperkuat penjelasan mengenai maksud yang akan disampaikan. Selain itu, pemilihan topik hasil penelitian tentang proses penyembuhan luka sayat ini ditujukan untuk memperjelas konsep bagian-bagian darah dan proses pembekuan darah. Submateri bagian-bagian darah dan pembekuan darah ini sangat cocok jika dikaitkan dengan proses penyembuhan luka. Hal ini disebabkan pada proses penyembuhan luka sangat erat kaitannya dengan peran sel-sel darah, sehingga di dalam submateri tersebut dikembangkan sebuah muatan mengenai materi kesehatan khususnya proses penyembuhan luka sayat.

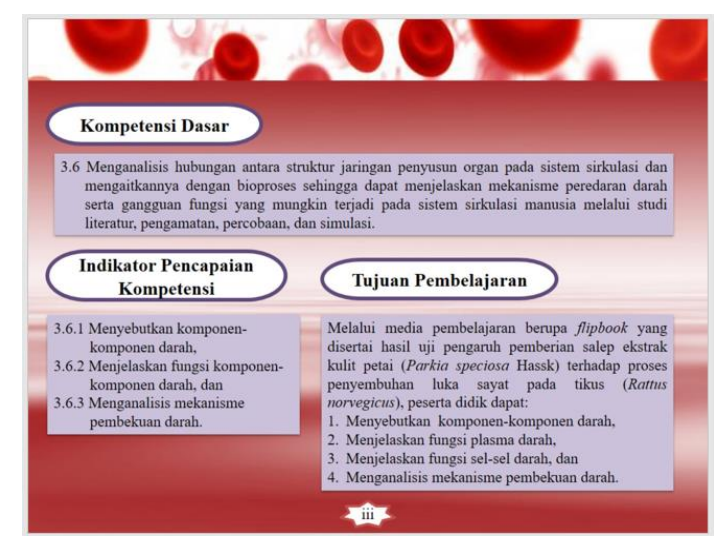

Gambar 2. Tampilan KD, IPK, dan Tujuan Pembelajaran

Gambar 2 menunjukkan tampilan KD, IPK, dan tujuan pembelajaran. menurut Ferazona (2017, p. 37-38) bahwa indikator adalah suatu penanda terhadap pencapaian kompetensi dasar (KD) melalui perubahan prilaku yang mencakup sikap, pengetahuan, dan keterampilan. Sehingga harus adanya kesesuaian antara indikator pencapaian kompetensi dan kompetensi dasar karena kompetensi dasar dapat dikembangkan menjadi beberapa indikator pencapain hasil belajar. Selain itu, kriteria pemilihan media juga harus sesuai dengan tujuan pembelajaran yang ingin dicapai (Arsyad, 2014, p. 74). 


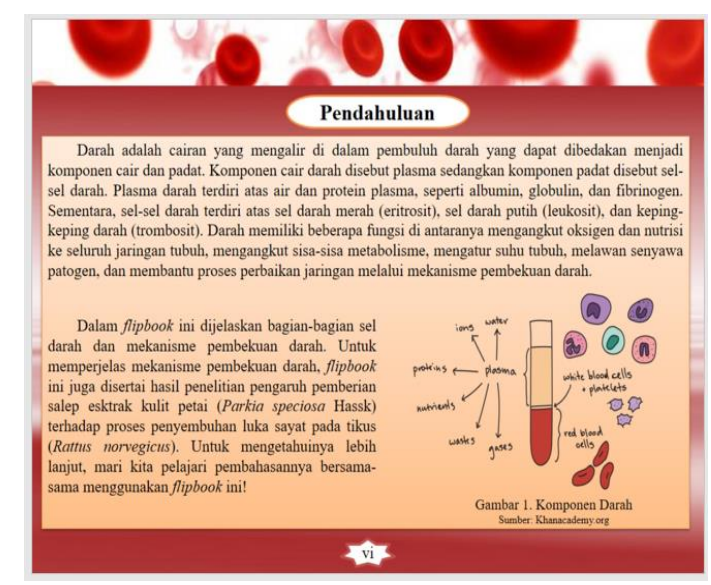

Gambar 3. Tampilan Pendahuluan Media Flipbook

Pentingnya pendahuluan dari sebuah materi sesuai dengan pernyataan Arroida (2018, p. 11) bahwa dalam penyajian materi harus terdapat pendahuluan yang lengkap serta menyajikan dan menjelaskan bagian-bagian yang menarik sehingga dapat menambah motivasi dan ketertarikan peserta didik dalam mempelajarinya. Pada gambar 3, bagian pendahuluan pada flipbook ini memuat tentang konsep darah, komponen-komponen darah beserta gambarnya.

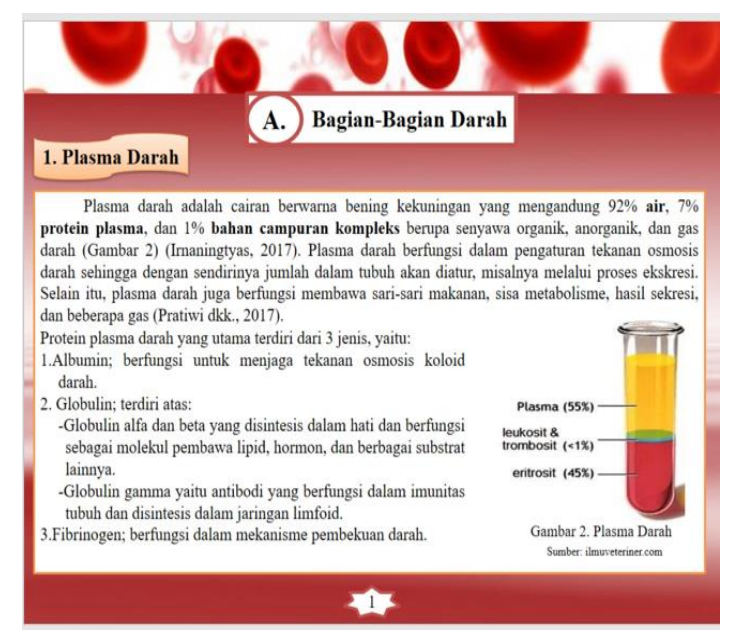

Gambar 4. Bagian Isi Media Flipbook

Pentingnya bagian isi pada sebuah media agar media yang dibuat dapat menyampaikan materi yang diharapkan dan menjadi pokok bahasan dalam proses pembelajaran. Bagian isi pada flipbook sebagaimana ditunjukkan pada gambar 4 memuat bagian-bagian darah yang meliputi plasma darah, sel darah putih (Leukosit), sel darah merah (Eritrosit), keping darah (Trombosit), dan proses pembekuan darah, beserta hasil penelitian tentang proses penyembuhan luka sayat. 


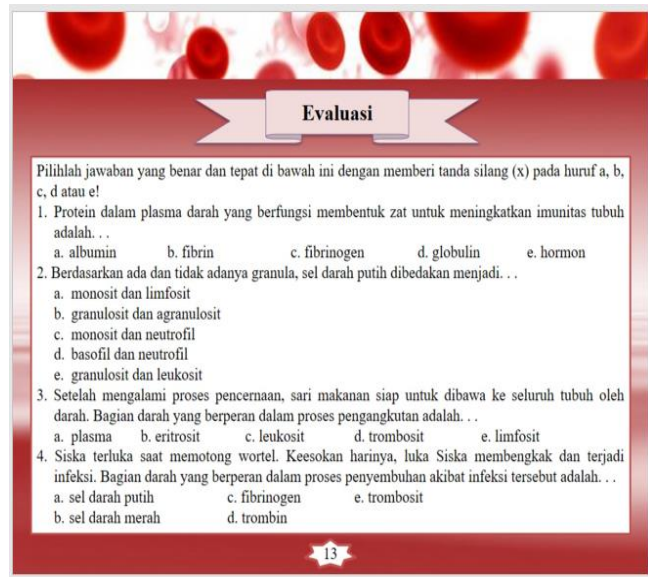

Gambar 5. Soal Evaluasi

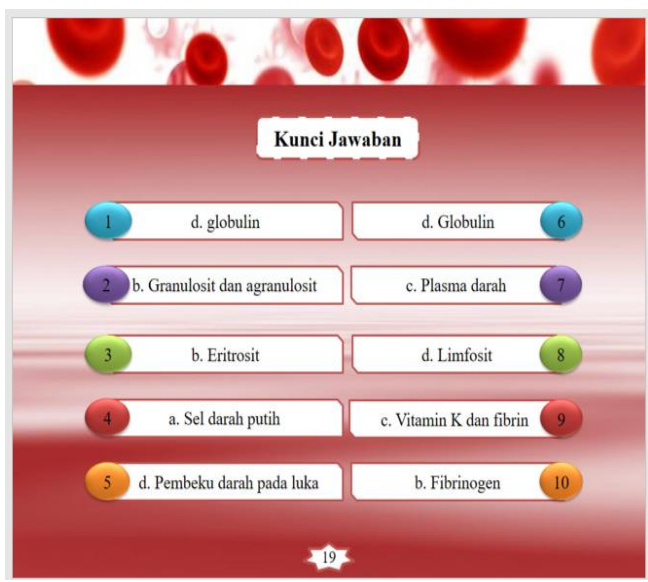

Gambar 6. Kunci Jawaban

Gambar 5 dan gambar 6 menunjukkan media flipbook yang dilengkapi dengan soal evaluasi beserta dengan kunci jawaban. Soal evaluasi pada sebuah media bertujuan untuk mengevaluasi terhadap penyerapan materi yang telah disampaikan dalam proses pembelajaran yang telah berlangsung (Anita dkk., 2018, p. 35). Sementara kunci jawaban dapat digunakan oleh peserta didik untuk menilai hasil jawaban mereka dengan melihat kunci jawaban yang telah disediakan.

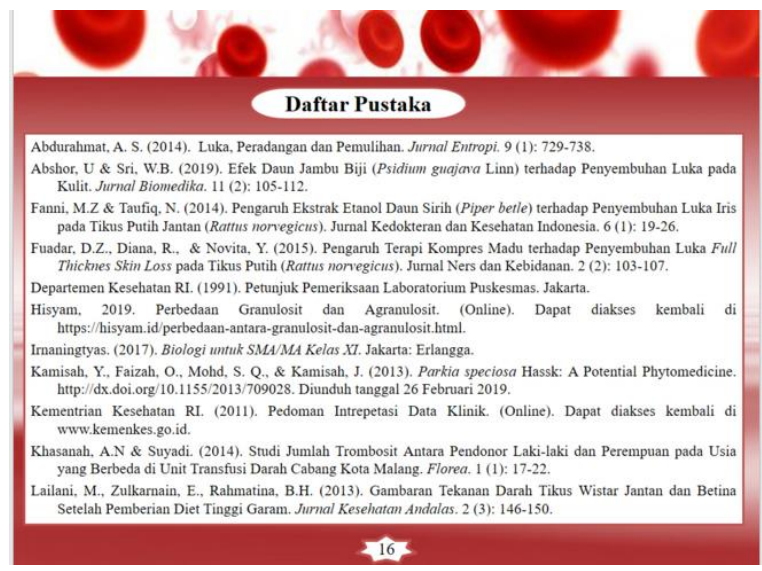

Gambar 7. Daftar Pustaka

Gambar 8 menunjukkan bagian daftar pustaka pada media. Menurut Sankarto (2014) daftar pustaka adalah sebuah daftar yang berisikan judul dari bukubuku, artikel-artikel, maupun bahan-bahan penerbitan lainnya yang berkaitan dengan sebuah karangan seperti skripsi, tesis dan artikel jurnal. Tujuan pembuatan daftar pustaka untuk memberikan suatu penghargaan terhadap sumber informasi dan ide orang lain yang telah digunakan serta memberikan petunjuk kepada pembaca mengenai sumber dari referensi (Sankarto, 2014). 


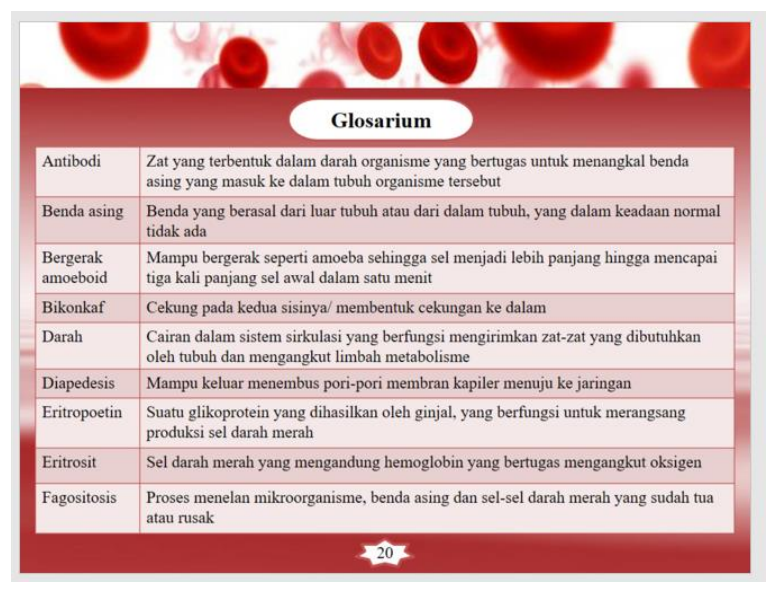

Gambar 8. Glosarium

Bagian glosarium pada gambar 8 digunakan untuk istilah-istilah penting yang baru diperkenalkan dan umumnya masih asing bagi pesert didik sehingga dengan adanya glosarium ini dapat mempermudah peserta didik untuk mengetahui istilah-istilah asing tersebut.

3. Tahap Pengembangan (Develop)

Media flipbook sebelum diujikan kepada peserta didik, terlebih dahulu dilakukan validasi untuk menguji tingkat kelayakannya. Tahap pengembangan (develop) bertujuan agar dapat menghasilkan media yang valid melalui uji validitas media (Adriani \& Sabeki., 2018, p. 77). Validasi media dilakukan oleh 5 orang validator terdiri dari 2 orang dosen FKIP UNTAN dan 3 orang guru Biologi SMA/MA di Kota Pontianak. Penilaian validasi flipbook terdiri dari 3 aspek terkait aspek format, isi, dan bahasa dengan 11 kriteria (Tabel 1).

Tabel 1. Analisis Data Validasi Media Flipbook pada Submateri Bagian-bagian Darah dan Pembekuan Darah

\begin{tabular}{ccccc}
\hline Aspek & \multicolumn{1}{c}{ Kriteria } & CVR & Keterangan \\
\hline Format & 1. Keserasian dan kekontrasan warna latar & 0,99 & Valid \\
& dan tulisan pada media flipbook & & \\
2. & Kesesuaian ukuran dan kejelasan gambar & 0,99 & Valid \\
& serta tabel pada media flipbook & & \\
3. Kelengkapan komponen dan urutan isi & 0,99 & Valid \\
& $\begin{array}{l}\text { pada flipbook } \\
\text { 4. Penggunaan ukuran dan jenis huruf yang }\end{array}$ & & \\
&
\end{tabular}


sesuai dan mudah dibaca pada jarak tertentu

5. Kesesuaian ukuran flipbook $(21 \times 28 \mathrm{~cm}) \quad 0,99 \quad$ Valid

Isi

6. Kesesuaian Submateri Bagian-Bagian

0,99 Valid

Darah dan Pembekuan Darah dengan 4 tujuan pembelajaran yang diharapkan

7. Kesesuaian antara indikator pencapaian 0,99 Valid kompetensi dan kompetensi dasar terhadap Submateri Bagian-Bagian Darah dan Pembekuan Darah

8. Kesesuaian dan keterkaitan pencantuman $0,99 \quad$ Valid hasil penelitian proses penyembuhan luka sayat untuk mendukung penyampaian Submateri Bagian-Bagian Darah dan Pembekuan Darah

Bahasa 9. Penggunaan bahasa Indonesia yang baik dan benar serta pembuatan kalimat yang mudah dipahami

10. Penggunaan tata bahasa sesuai dengan 0,99 Valid Pedoman Umum Ejaan Bahasa Indonesia (PUEBI)

11. Keefektifan kalimat yang digunakan pada $0,99 \quad$ Valid media flipbook

CVI 0,99 Valid

Penilaian pada aspek isi/materi untuk setiap kriteria memperoleh skor 0,99 yang dikategorikan valid. Penyajian isi/materi harus sesuai dengan kompetensi dasar (KD), indikator, dan tujuan pembelajaran karena ketiganya mempunyai perannya masing-masing dalam proses pembelajaran. Menurut Ferazona (2017, p. 38), setiap kompetensi dasar dapat dikembangkan menjadi beberapa indikator pencapaian sebagai pedoman untuk mengukur kemampuan peserta didik terhadap materi yang disampaikan. Habibina et al., Flipbook Bagian-Bagian Darah 
Selain itu, tujuan pembelajaran merupakan faktor yang sangat penting dalam proses pembelajaran karena dengan tercapainya tujuan pembelajaran, maka guru dapat dikatakan telah berhasil dalam mengajar (Pane \& Dasopang., 2017, p. 334)

Penilaian pada aspek bahasa untuk setiap kriteria memperoleh skor 0,99 yang dikategorikan valid. Penggunaan kalimat dalam penyampaian materi harus menggunakan bahasa yang mudah dipahami. Sesuai dengan pendapat Sanjaya (2008, p. 152) bahwa bahan pelajaran harus disajikan dengan tidak banyak menggunakan kalimat majemuk, bahasa yang komunikatif, dan makna yang dimaksud mudah dipahami. Pendapat Kurniasari dkk. (2014, p. 463) menyatakan bahwa diperlukan suatu inovasi terhadap bahan ajar agar lebih mudah dipahami dengan menggunakan kata-kata yang sederhana namun tidak mengesampingkan makna yang sesungguhnya dan menampilkan berbagai ilustrasi yang menarik.

Secara keseluruhan, setiap aspek memperoleh nilai CVR dan CVI sebesar 0,99 atau sesuai dengan nilai minimum dari content validity menurut Lawshe (1975) untuk lima validator. Dengan demikian, flipbook yang memuat pengayaan informasi tentang proses wound healing dapat dikategorikan valid dan layak digunakan sebagai media pembelajaran pada submateri Bagian-bagian Darah dan Pembekuan Darah kelas XI SMA. Pengayaan informasi proses wound healing meningkatkan pencapaian KD 3.6 dengan memberikan contoh langsung tentang peran masing-masing bagian-bagian darah pada proses pembekuan darah. Bahkan, peserta didik mendapatkan informasi tambahan berupa fase-fase yang terjadi pada saat proses penyembuhan luka secara utuh yang meliputi fase inflamasi, proliferasi, dan maturasi. Pada tahap selanjutnya, perlu dilakukan pengujian secara langsung dalam proses pembelajaran di kelas untuk melihat kebermaknaan topik pengayaan yang ditambahkan dalam flipbook ini dari sisi peserta didik dengan harapan dapat menemukan kesesuaiannya dalam kehidupan sehari-hari.

\section{KESIMPULAN DAN SARAN}

Proses pengembangan media flipbook dengan menggunakan 3 dari 4 tahap dalam model 4D dapat memberikan hasil produk yang valid dan layak digunakan dalam pembelajaran Submateri Bagian-bagian Darah dan Pembekuan Darah kelas XI SMA. Pada tahap berikutnya dalam model 4D yaitu disseminate perlu dilanjutkan untuk mengetahuai kesesuaiannya dalam pembelajaran secara langsung. Selanjutnya, perlu 
dilakukan pengujian secara langsung dalam proses pembelajaran untuk melihat kebermaknaan topik pengayaan yang ditambahkan dalam flipbook ini.

\section{DAFTAR PUSTAKA}

Adriani, N., \& Sabeki, A. W. (2018). Tingkat Validasi Media Pembelajaran Kimia Berbasis Android Validity of Android-Based Chemsitry Learning Media. Jurnal Zarah 6(2), 76-80.

Andri, Y., Syamswisna., \& Yeni, L. F. (2013). Efektivitas Pembelajaran Kooperatif Berbantuan Media Flipbook Terhadap Hasil Belajar Siswa Sistem Gerak Manusia di SMP. Jurnal Pendidikan dan Pembelajaran 2(6), 1-9.

Anita., Tyowati, S., \& Zuldafrial. (2018). Analisis Kualitas Butir Soal Fisika Kelas X Sekolah Menengah Atas. Edukasi: Jurnal Pendidikan 16(1), 35-47.

Ariani, P., Daningsih, E., \& Yokhebed. (2017). Kelayakan Media Flipbook Upaya Pencegahan Pencemaran Udara Kelas X. Jurnal Pendidikan dan Pembelajaran Khatulistiwa 6(1), 1-11.

Arroida, A. K. (2018). Analisis Buku Teks Pelajaran Matematika Wajib Kelas X SMA. Jurnal Pendidikan Matematika 7(3), 1-13.

Arsyad, A. (2014). Media Pembelajaran. PT Raja Grafindo Persada. Jakarta.

Ferazona, S. (2017). Analisis Kesesuaian Materi Instrumen Evaluasi dengan Indikator pada RPP Materi Plantae dan Sistem Ekskresi di SMA Kota Bandung. Jurnal BIOnatural 4(2), 28-41.

Habibina. (2020). Kelayakan Flipbook Submateri Bagian-bagian Darah dan Pembekuan Darah Berdasarkan Uji Pengaruh Salep Ekstrak Etanol Kulit Petai (Parkia speciosa Hassk) terhadap Proses Penyembuhan Luka Sayat pada Tikus (Rattus norvegicus). Skripsi. Universitas Tanjungpura Pontianak.

Kurniasari, D. A. D., Rusilowati, A., \& Subekti, N. (2014). Pengembangan Buku Suplemen IPA Terpadu Dengan Tema Pendengaran Kelas VIII. Unnes Science Education Journal. 3(2): 462-467.

Lawshe, C. H. (1975). A Quantitative Approach to Content Validity. Purdue University. Personnel Psychology 28, 563-575. 
Lestari, D., Sri, M. E. S., \& Susanti, R. (2016). Pengembangan Perangkat Blended Learning Sistem Saraf Manusia untuk Meningkatkan Keterampilan Berfikir Kritis. Journal of Innovative Science Education 2(2), 83-93.

Lestari, I., Eka, A., \& Reni, M. (2016). Efektivitas Pembelajaran Kooperatif Berbantuan Flipbook terhadap Hasil Belajar Siswa pada Materi Virus di SMA. Jurnal Pendidikan dan Pembelajaran Khatulistiwa 5(6), 1-13.

Lubis, A. R \& Manurung, B. (2010). Pengaruh Model dan Media Pembelajaran terhadap Hasil Belajar dan Retensi Siswa pada Pelajaran Biologi di SMP Swasta Muhammadiyah Serbelawan. Jurnal Pendidikan Biologi 1(3), 186-206.

Maf'ula, A., Hastuti, U. S., \& Rohman, F. (2017). Pengembangan Media Flipbook Pada Materi Daya Antibakteri Tanaman Obat Berkhasiat. Jurnal Pendidikan: Teori, Penelitian, dan Pengembangan 2(11), 1450-1455.

Maghfirothri, N. L., Mitarlis., \& Widodo, W. (2013). Pengembangan Flipbook IPA Terpadu Bilingual dengan Tema Minuman Berkarbonasi untuk Kelas VIII SMP. Jurnal Pendidikan Sains e-Pensa 1(3), 42-47.

Monica \& Luzar, L. C. (2011). Efek Warna dalam Dunia Desain dan Periklanan, Humaniora 2(2), 1084-1096.

Mulyadi, D. U., Wahyuni, S., \& Handayani, R. D. (2016). Pengembangan Flash Flipbook untuk Meningkatkan Keterampilan Berfikir Kreatif Siswa dalam Pembelajaran IPA di SMP. Jurnal Pembelajaran Fisika 4(4), 296-301.

Niagara., Daningsih, E., \& Titin. (2018). Kelayakan Flipbook Materi Berbagai Tingkat Keanekaragaman Hayati Indonesia dari Buah Peluntan, Senare, dan Ara'. Jurnal Pendidikan dan Pembelajaran Khatulistiwa 7(5).

Nugroho, H., Syamswisna., \& Yokhebed. (2016). Kelayakan Media Flash Flipbook pada Submateri Manfaat Keanekaragaman Hayati untuk Kelas X SMA. Jurnal Pendidikan dan Pembelajaran Khatulistiwa 5(9), 1-10.

Nurseto, T. (2011). Membuat Media Pembelajaran yang Menarik. Jurnal Ekonomi dan Pendidikan 8(1), 19-35.

Pane, A \& Dasopang, M. D. (2017). Belajar dan Pembelajaran. Fitrah: Jurnal Kajian Ilmu-ilmu Keislaman 3(2), 333-352. 
Rohdiani, F \& Rakhmawati, L. (2017). Pengembangan Media Pembelajaran Berbasis Web pada Mata Pelajaran Dasar Elektronika di SMK Negeri 3 Jombang. Jurnal Pendidikan Teknik Elektro 6(1), 105-110.

Sakhowati., Khotimah, K., \& Putra, I. A. (2020). Pengembangan Media Pembelajaran Flipbook di SMA PGRI 1 Kelas XI IPA 1 Materi Elastisitas dan Hukum Hooke. EDUSCOPE: Jurnal Pendidikan, Pembelajaran, dan Teknologi 6(1), 46-52.

Sanjaya, W. (2008). Perencanaan dan Desain Sistem Pembelajaran. Prenadamedia Group. Jakarta.

Sankarto, B. S. (2014). Sistem Kepustakaan Dalam Karya Tulis Ilmiah (KTI). Workshop Statistika dan Metodologi Penelitian.

Simamora, A. M., \& Mukhtar. (2015). Pengembangan Media Pembelajaran Kalimat Efektif Pada Pelajaran Bahasa Indonesia. Jurnal Teknologi Informasi \& Komunikasi dalam Pendidikan 2(2): 201-214.

Syafrizal, S., Yeni, L. F., \& Titin. (2014). Inventarisasi Jamur Makroskopis di Hutan Adat Kantuk dan Implementasi dalam Pembuatan Flipbook. Jurnal Pendidikan dan Pembelajaran Khatulistiwa 3(9), 1-15.

Thiagarajan, S., Semmel, D. S., \& Semmel, M. I. (1974). Instructional Development for Training Teacher of Expectional Children. Bloomington Indiana: Indiana University.

Utariyanti, I. F. Z., Wahyuni, S., \& Zaenab, S. (2015). Pengembangan Media Pembelajaran Berbasis Komik dalam Materi Sistem Pernafasan pada Siswa Kelas VIII MTs Muhammadiyah 1 Malang. Jurnal Pendidikan Biologi Indonesia 1(3), 343-355.

Wahyuliani, Y., Supriadi, U., \& Anwar, S. (2016). Efektivitas Penggunaan Media Pembelajaran Flipbook Terhadap Peningkatan Hasil Belajar Siswa Pada Mata Pelajaran PAI Dan Budi Pekerti di SMA Negeri 4 Bandung. TARBAWY Indonesian Journal of Islamic Education 3(1), 22-36. 